Прегледни чланак

Irina Sferdian, Ph.D., Professor

West University of Timisoara

Faculty of Law

irina.sferdian@e-uvt.ro

Codruţa Guzei-Mangu, Ph.D., Senior Lecturer

West University of Timisoara

Faculty of Law

codruta.mangu@e-uvt.ro

\title{
ACQUIRING LAND OWNERSHIP RIGHTS IN ROMANIA BY FOREIGN CITIZENS
}

Abstract: The present paper deals with the subject of the acquisition of land ownership in Romania by foreign citizens. It presents the legal problems involved matter in relation to the legal regime drawn by the three essential laws in the field, Law 312/2005, Law 18/1991 and Law 17/2014, to which are added the constitutional provisions regarding this subject. The legal regime under which land in Romania can be acquired by foreign citizens is presented depending on the fact that the foreign citizens are members of the European Union or they are foreign citizens belonging to third countries. Also, an important place in this study is reserved to the explaining of the meaning of the term reciprocity in this matter and to the functioning mechanism of the preemption right in connection with the acquisition of land ownership right in Romania by foreign citizens.

Keywords: acquisition of land ownership in Romania, foreign citizens, agricultural land, immovable property, preemption right, reciprocity, RomanianTurkish Agreement.

\section{INTRODUCTION}

All lands in Romania, irrespective of their destination, the holder, the title on which they are owned and their belonging to the public domain or to the private domain, constitutes the land fund of Romania, pursuant to art. 1 of the Land Fund Law no. 18/1991. 
According to land use, they are categorized in art. 2 of Law no. 18/1991, in the following categories:

„a) Agricultural land, namely: agricultural arable land, vineyards, orchards, vineyard nurseries, fruit trees, hop and mulberry trees, pastures, hayfields, greenhouses, solariums, ponds and the like, those with forest vegetation, if they are not a part of forestry arrangements, wooded pastures, agrozootechnical constructions and facilities, fish farming and land improvements, technological and agricultural roads, warehouse platforms and storage facilities that serve the needs of agricultural production and non-productive land that can be arranged and used for Agricultural production;

b) Land with a forestry purpose, such as: wooded or crop land, forestry production or management, land for afforestation and non-productive land - rocks, abrupt, boulders, ravines, ravines, torrents - if included in the forestry arrangements;

c) Land permanently under water, such as: minor watercourses, lake's basins at maximum containment levels, bottom of inland maritime and territorial seas;

d) Urban land of urban and rural localities on which are located the constructions, other settlements of the localities, including agricultural and forest lands;

e) Land for special purposes such as those used for road, rail, naval and air transport, construction and associated facilities, construction and hydrotechnical, thermal, power and natural gas transmission, telecommunications, mining and petroleum operations, quarries and heaps of any kind, for defense needs, beaches, reservations, natural monuments, archaeological and historical sites, and others like these.“

The lands belonging to the public domain are those affected by public utilities and the legal regime applicable to them is that of the public property right. These lands are inalienable, imprescriptible and not subjected to forced execution. They cannot be entered into the civil circuit except under the conditions provided by law, by decommissioning them of the public domain.

The lands subject to the right of private property are in the civil circuit and, irrespective of whether it belongs to natural or legal persons governed by private law or public law, in principle, have a free movement regime, that is, they can be acquired by anyone without restrictions. However, the principle of the free movement of private property is subject, at the moment, to legal limitations justified by ensuring the security of the civil circuit.

The current legislation ${ }^{1}$ only provides for minimum restrictions on the acquisition of the right to private property or the exercise of the private property

${ }^{1}$ Starting with 1947, the political regime established in Romania imposed restrictive regulations on private property, many of which referred to the legal circulation of land. By successive laws, it was mainly intended to legislate the authentication of legal acts relating to land, to obtain prior administrative authorization for alienation property right, to limit the acquisition of agricultural land by inheritance only to direct or collateral relatives up to the third degree, including spouses. Subsequently, the land without construction, property of the natural or legal 
right on the land, in order to allow the securing of land transactions, as well as a better knowledge of Romania's land stock and better exploitation of it

\section{LEGAL RESTRICTIONS ON FREE MOVEMENT OF LAND}

The Romanian Constitution stipulates in art. 44 par. (2), second thesis, the fact that foreign citizens and stateless persons may acquire the right to private ownership of land only in the conditions resulting from the joining of Romania to the European Union and other international treaties to which Romania is a party, on a reciprocal basis, and by legal inheritance.

In our attempt to determine the content of the notion of reciprocity, a sine qua non condition for the acquisition of land ownership by third-country nationals, we feel it would be useful to do this by referring to a concrete example in this matter. For this reason, we will focus our attention on the provisions of the Agreement between the Government of Romania and the Government of the Republic of Turkey on the Promotion and the Safeguarding of Investments ${ }^{2}$, thus trying to discover the way in which such a normative act is drafted and how, in this matter, the conditions of reciprocity can be expressed and understood.

Desiring to develop the existing economic cooperation relations between the two countries and to encourage the creation of favorable conditions for the investments of the Romanian investors on the territory of the Republic of Turkey and of the investors from the Republic of Turkey on the territory of Romania, the two States have signed this Agreement which, among other conferred rights, grants to the signatory parties, subject to the conditions imposed by this Agreement, the prerogative to acquire ownership of the immovable property in the territory of each of the signatory States.

persons in the urban and urban areas became unavailable and the subject of expropriation (Law No. 19/1968), and by Laws 58/1974 and 59/1974 all categories of land were removed from the civil circuit. The lands in the buildable perimeter of urban and rural settlements could be acquired only through legal inheritance, their acquisition through legal acts between living persons being forbidden. If the constructions were alienated, their land was lawfully transferred to state ownership. Since December 1989, these laws have been abolished, and, regarding this matter, land law regulations being Law no. 18/1991 regarding the land fund, Law no. 54/1998 on the legal circulation of land, which repealed the articles referring to the legal circulation of land under Law no. 18/1991, Law no. 247/2005 on property and justice reform, as well as some adjacent measures, which by art. 8 of Title X repealed Law no. 54/1998. As for Title X of Law no. 247/2005 regarding the legal circulation of land, it was repealed by Law no. 71/2011 for the implementation of Law no. 287/2009 on the Civil Code. See E. Chelaru, Legal Circulation of Land, Edit. All Beck, Bucharest, 1999, p. 48,142; C. Bîrsan, V. Stoica, Evolution of legislation on the circulation of buildings, II, in Law no. 6/1990, p. 45 49; D. Chirică, The Consequences of the Post-revolutionary Legislative Changes on the Movement of Private Property, in Law no. 6/1991, p. 25 27; E. Chelaru, Civil Law. The Rigts in rem, ed. 3 a, Ed. C.H. Beck, Bucharest, 2009, p. 123, 180.

${ }^{2}$ Published in the Official Monitor of Romania and in force since February $23^{\text {rd }}, 2009$. 
Thus, as announced in the title of the Agreement, the essential condition to be taken into consideration by the parties is that the acquisition of ownership of immovable property is to be done for the purpose of investing in the territory of the other country. In this regard, according to art.1 of the Agreement, investment term means, in accordance with the national laws and regulations of the contracting party hosting the investment, any assets and includes, but is not limited to those listed, the right of the parties to "movable and immovable property and rights such as mortgages, guarantees and pledges or similar ownership rights ". Considering the content of this normative text, we can see that the parties are given the right to acquire real estate ownership in the territory of the other country, and, as long as the text does not explicitly stipulate what kind of immovable property is referring to, the interpretation can be made in the sense that the parties are offered the opportunity to acquire real estate (immovable property), constructions and land, either inside or out of town, of the urban area.

Together with the essential condition allowing the acquisition of ownership of immovable property, that is, its acquisition for investment purposes, the Agreement also sets out other rules that parties must obey in order to exercise the rights granted by it.

In this regard, we can distinguish between the following guidelines: acquiring ownership of immovable property will be done in accordance with the national laws and regulations of the state in which acquisition takes place (Article 2, paragraph 1); The acquisition of property will take place without prejudice to the measures adopted by the European Union; Investment by investors of either contracting party will always be fair and equitable and will enjoy adequate protection in the territory of the other contracting party; No contracting party shall, through unreasonable or discriminatory measures, affect the management, maintenance, use, possession, extension or administration of such investments (Article 2 (2)); Each contracting party shall grant to its investors in the territory of the other contracting party treatment no less favorable than that it accords to its investors or investors of a third state, whichever is the more favorable (Article 3 (1)).

As it can be seen, the optics of the clauses stipulated in the Agreement is a general one, to which the parties must relate, and the effective acquisition of the property right is to be achieved in compliance with the requirements and rigidities found in national laws of the state where the immovable property in which the acquisition takes place.

Therefore, considering the provisions of the Romanian-Turkish Agreement and also the constitutional provisions of art. 44 par. $2^{3}$, we find that the central

3 "Private property is guaranteed and protected equally by law, regardless of the holder. Foreign citizens and stateless persons may acquire the right to private land ownership only in the conditions resulting from the joining of Romania to the European Union and other international 
idea, namely, the premise of the existence of the right to acquire land ownership, is the requirement of reciprocity.

In trying to delineate this requirement, it is obvious that reciprocity refers to the fact that each state must recognize in favor of the other the prerogative of acquiring in its territory the right to ownership of land. Furthermore, in order to exercise this prerogative, each state may establish one or more common conditions, such as the acquisition of property for the purpose of investment found in the Romanian-Turkish Agreement, these conditions being imposed by both States, and, in case of non-fulfillment, the right to acquire land ownership cannot be exercised in a valid way. Next, the following common point which characterizes reciprocity is that the exercise of the rights granted to the citizens of the two states should benefit of a fair and equitable treatment, on the basis of which the other party will not have a less favorable legal status than that applied to a third state which is part of an agreement that regulates on the same matter.

Another important provision in terms of reciprocity is that, for the purpose of exercising the right conferred by the Agreement, the parties of each state are required to respect the national laws and regulations of each state regarding the conditions to be met in order to acquire ownership of the land. From this last requirement, to which reciprocity refers to, results two essential aspects: the first is that by complying to the law and national regulations by the parties, as they are naturally subject to the same legal rules as the citizens of each of the states, they will not benefit from more favorable treatment, neither in comparison with them, nor with European citizens; the second refers to the idea that, by enforcing national law and regulations, the parts of third states will not be subject to a more severe legal regime than that imposed on the citizens of the signatory states. On the other hand, regarding the condition of observing the national law of each state, we believe that reciprocity is limited to the actual content of the national provisions, in the sense that the laws and regulations of each state must not have provisions that outline a legal regime identical to that of the other State in the matter of acquiring land ownership, and it is even possible for the stipulations in the national laws of one of the states to be more severe or more restrictive than those provided for in the national regulations of the other state. Thus, reciprocity is limited to compel the parties to that the acquisition of land ownership will be done in accordance with the general and special provisions found in national law. So, reciprocity does not require that national regulations from the signatory states should create the same legal regime. One last aspect that we consider to be mentioned and also what is presented in close connection with the idea of reciprocity is, as it results from the lines of the Romanian-Turkish Agreement, that, whatever

treaties to which Romania is a party, on the basis of reciprocity under the conditions provided by organic law, as well as through legal inheritance." 
the stipulations to be applied mutually between the parties, they must be in compliance with the rights and measures drawn from the quality of the Romanian state as a Member State in the European Union, thus respecting the rights granted to the European citizens in this matter.

\section{a) Land acquisition in Romania by foreign citizens, stateless persons and foreign legal persons under Law no. 312/2005}

The normative act regulating the way in which foreign citizens, stateless persons and foreign legal persons acquire ownership of land in Romania is Law no. $312 / 2005^{4}$.

According to art. 3 of the Law no. 312/2005, "The citizen of an EU Member State, the stateless person domiciled in a Member State or in Romania and the legal person established under the law of a member state may acquire ownership of the land under the same conditions as those provided for by law for Romanian citizens and for Romanian legal persons ". According to art. 1 paragraph (2) of Law no. 312/2005, "The provisions of the present law do not apply to the acquisition of land ownership by foreign citizens and stateless persons by legal inheritance", in which case the provisions of the common law in matters of inheritance shall apply.

Regarding the testamentary heirs, the provisions applicable to them are those of the Art. 3 of the Law no. 312/2015, given the fact that this is the rule in the matter of acquiring the right of ownership by foreign citizens and stateless persons.

Exceptions to the rule in Art. 3 of the Law no. 312/2005 are stipulated in Art. 4, which states that the acquisition of the right of ownership over the lands can be achieved by foreign citizens and stateless persons residing abroad only by establishing residence in Romania and in art. 5, which restricts the acquisition of land not by the quality of the land but by the nature of the land, referring to agricultural land, forests and forest land.

Thus, according to art. 4 of the Law no. 312/2005, "The citizen of a non-resident Member State in Romania, a non-resident stateless person in Romania domiciled in a Member State, as well as a non-resident legal person constituted in accordance with the legislation of a Member State, may acquire the ownership of land for secondary residences, respectively secondary offices, at the expiration of 5 years period from the date of Romania's joining the European Union “.

Acquisition of the land must be done for the purposes of establishing residence in Romania by foreign nationals of Member States and stateless persons domiciled in Member States. Legal entities established in an EU Member State

${ }^{4}$ Law no. 312/2005 was published in the Official Monitor of Romania, Part I, no. 1008 of November $14^{\text {th }}, 2005$. 
may acquire land in Romania for the establishment of a secondary offices. This means that if the purpose of establishing a residence in Romania for individuals or a secondary establishment offices for legal persons is not met, foreign citizens, stateless persons and foreign legal persons cannot, currently, acquire land in Romania.

Although, at the first reading of the law would result that foreign citizens in the Member States and stateless persons domiciled in a Member State cannot acquire the right to land ownership in Romania for 5 years from the date of Romania's joining the EU, and at the end of the 5 year period, providing that a residence in Romania has been established, interpretation in the doctrine and judicial practice in our country was made in the sense that that foreign citizens and stateless persons domiciled in a Member State can acquire ownership of land in Romania, from the date of joining the EU, if they are resident in Romania. Thus, it would mean that the only condition for becoming a landowner in Romania for this category of citizens is linked to the quality of the resident. In our opinion, this interpretation does not comply with the letter of the law and we do not consider that this was the intention of the legislator, since it provided expressly the possibility of the acquisition of land ownership by citizens of the Member States only for the purposes of establishing their residence in Romania, 5 years from the date of Romania's joining the EU. The interpretation given to this law by practitioners of law in Romania takes out the meaning of the provision of a 5-year period, since requires only the quality of resident in Romania in order to acquire ownership of land.

The fact that Art. 4 of the Law no. 312/2005 had to be interpreted in the sense that we have shown is proven by the exception stipulated in art. 5 of the Act, which refers to a certain category of land, agricultural ones, forests and forest lands. Thus, according to art. 5 par. (1) of Law no. 312/2005, "A citizen of a Member State, a stateless person domiciled in a Member State or in Romania, and a legal person, constituted under the law of a Member State, may acquire the right to property on agricultural land, forests and forestry land upon completion of a 7 year term from the date of Romania's joining the European Union ". By exception, according to par. (2) of the same article, "The provisions of paragraph (1) shall not apply to self-employed farmers who are: a) nationals of Member States or stateless persons domiciled in a Member State who establish their residence in Romania; B) stateless person with domicile in Romania ". As a result, the latter may acquire ownership of these special purpose land even from the date of Romania's joining the European Union if they prove that they are independent farmers and establish their residence in Romania or, in the case of stateless persons who do not have their domicile Member States, if they establish their domicile in Romania.

Proof of the status of independent farmer shall be made with documents issued, as the case may be, by the competent authorities "in the Member State or that of origin" or by the certificate issued by the competent authorities in Romania. 
These persons are required to keep the purpose in which the acquired land is used land for a period of 7 years, calculated from the date of Romania's joining the European Union.

Therefore, regarding these special-purpose land, self-employed farmers who, being citizens or stateless persons domiciled in a Member State, establish their residence in Romania, as well as stateless persons residing in Romania, may acquire the right to ownership of land as of the date of joining the EU, provided that the land use category is kept for 7 years from the date of the joining. If the legislator had intended to admit the acquisition of any land from the date of Romania's joining the EU by foreign citizens in the Member States and stateless persons who have their domicile in a Member States, but residing in Romania, he would have stipulated it expressly, as he did in the case of farmers, regarding agricultural land, forests and forest land.

Those who are not farmers, in order to acquire ownership of agricultural land, forests and forest lands must obtain residence in Romania and must wait for the 7 year period from the date of acquisition to pass. This period of time expired on 1 January 2014.

Therefore, at the present time, the 5-year period applicable to the acquisition of land other than agricultural, forest and forest land has expired, as well as the 7 years applicable to these special categories of land.

Thus, the only condition currently required for the acquisition of land in Romania by foreign citizens or stateless persons domiciled in an EU Member State or the European Economic Area, namely the one referring the purpose of such acquisition, that is establishing a residence in Romania.

It is necessary to distinguish between the right of residence of foreign citizens and stateless persons and the quality of resident in Romania.

Regarding the right of residence on the territory of Romania, art. 11 from Government Emergency Ordinance no. 102/2005 on the free movement on the territory of Romania of the citizens of the member states of the European Union, the European Economic Area and the citizens of the Swiss Confederation ${ }^{5}$, the citizens of the European Union who enter Romania have the right of temporary residence for a period of up to 3 months from the time of their entry into the country, and if they are looking for a job, they have the right to reside for a period of up to 6 months from the date of entry, no other additional formalities required.

The right of residence on Romanian territory is granted for a period longer than 3 months if the persons in question are in one of the following situations: A) they have the status of a worker; B) they have means of subsistence for them and their family members, usually the minimum guaranteed income in Romania, and

${ }^{5}$ O.U.G. no. 102/2005 was republished in the Official Monitor of Romania, Part I, no. 774 of 2 November 2011. 
health insurance; C) are enrolled in an accredited Romanian educational or training institution, have health insurance and have means of support for them and their family members, usually the minimum guaranteed income in Romania; D) they are family members of a citizen of the European Union meets one of these conditions or of a Romanian citizen domiciled or residing in Romania (Article 12 of the Ordinance).

Family members who are not citizens of the European Union can benefit of the right of residence for more than 3 months if they accompany or join the European Union citizen who meets one of the conditions laid down by law.

It follows that the right of residence implies a certain period in which the person in question lived on the territory of Romania and met the registration formalities with the competent authorities, a simple entry on the Romanian territory not being enough ${ }^{6}$. We consider that the intention of the legislator was to allow the acquisition of land in Romania only to those who are to establish secondary residences on the territory of Romania?

Regarding the foreign legal person, the special law does not explain what we need to understand through the secondary establishment of the legal person. In the case of Romanian legal persons, the provisions of art. 227 The Romanian Civil Code stipulates that its registered office shall be established according to the constitutive act or the statute, and depending on the object of activity, the legal person may have several secondary offices for branches, territorial offices and work points. Also, art. 227 par. (2) The second sentence of the Romanian Civil Code makes reference, regarding the establishment of the Romanian legal person's office, to the provisions of art. 97 Romanian Civil Code, which regulates the chosen place of residence of the natural person, and which may be established upon the conclusion of a certain legal act, in writing, in order to exercise the rights and obligations arising from that act.

The foreign legal person, established in the country of origin, may have secondary offices for the carrying on of the activity, under the conditions stipulated in its constitutive documents, in compliance with the foreign law regulations

${ }^{6}$ In the same regard, E. Chelaru, Civil Law. The main rights in rem, op. cit., p. 179 180. For the opinion that the physical presence in Romania of a foreign citizen or a stateless person residing in a Member State of the European Union is sufficient for him / her to be able to acquire ownership of the land under the same conditions as Romanian citizens, see C. Drăguşin, D. Birlog, Acquisition of the right to land ownership by foreign citizens, stateless persons and foreign legal persons after Romania's accession to the European Union, in Law no. 6/2007, p. 2327.

${ }^{7}$ For Romanian citizens, the residence is the place where the individual declares that he / she has his / her secondary residence (Article 88 Civil Code), Unlike his / her domicile, which is the place where the individual declares that he / she has his / her main residence (art. 87 Civil Code). Also, the provisions of Art. 86 para. (2) Romanian Civil Code, according to which a natural person cannot have at the same time more than one domicile (home) and one residence, even when he has several dwellings. 
under which it was constituted and which is applicable to it. The provisions of private international law provide in art. 2582 The Romanian Civil Code, that the foreign legal persons constituted for lucrative purposes, validly constituted in the state whose nationality they have, are fully recognized in Romania, and non-profit legal persons can be recognized in Romania, on the basis of the Government's prior approval, by a court order, subject to reciprocity, if they are validly constituted in the state whose nationality they have and if the statutory purposes they pursue do not contravene the social and economic order in Romania.

According to art. 2580 Romanian Civil Code, the organic status of the foreign legal person is governed by its national law, and the organic status of the branch established by the legal person in another country is subject to the national law of the legal person.

Foreign citizens, stateless persons and foreign legal persons belonging to third countries cannot acquire ownership of land under more favorable conditions than those applicable to those in member states of the European Union. In addition, foreign citizens and stateless persons may acquire land in Romania in the conditions resulting from the international treaties to which Romania is a party and on the basis of reciprocity.

\section{b) Acquisition of land ownership by foreign citizens by restitution of land rights under Law no. 18/1991}

With the revision of the Romanian Constitution, the question was whether the heirs, foreign citizens of a deceased author, may or may not acquire ownership of the land by way of restitution after that author, through Law no. 18/1991 (land fund law).

Some authors ${ }^{8}$ have expressed the opinion that foreign citizens cannot acquire ownership by restitution under Law no. 18/1991 for the following arguments:

- the subject of the Law no. 18/1991 is the land fund of Romania;

- regulating the way in which restitution works, including that regarding the entitled persons, is the legislator's choice, in accordance with the purpose of the law;

- the constitutional review on October 29,2003, which allows the acquisition by foreign citizens and stateless persons of the ownership of land by way of legal inheritance, concerns an acquisition under the conditions of the common law, and Law no. 18/1991 republished is a special law that has as its recipients only the Romanian citizens;

${ }^{8}$ For details regarding this opinion and the succession of regulations in the matter, see Simona Kovacs, "The Right of Foreign Citizens to Reconstruct the Land Ownership as the Owners' Heroes," Journal of the Judges Forum, available online at: http://www.forumul judecatorilor.ro/ index.php/2009/11/dreptul-cetatenilor-straini-la-reconstituirea-dreptului-de-proprietate-asupraterenurilor-in-calitate-de-mostenitori-ai-autorului-lor/ 
- art. 48 of the Law no. 18/1991 was the subject of the objection of unconstitutionality which was rejected, so only those who prove their status as Romanian citizens (their or their author), on the date when the law of reparation came into force, can acquire ownership of land by way of legal inheritance;

- only if the author died after the constitutional review (after 29.10.2003), his heirs can acquire land ownership by restitution, because the applicable law is that from the date of the inheritance, so only after 29.10 .2003 ownership of land by way of legal inheritance can acquired by foreign citizens.

In another opinion, it is thought that nowadays foreign citizens can acquire land ownership by way of restitution, but only as heirs, and not in their own name.

Art. 47 of the Law no. 18/1991, in its original form (in force on 20.02.1991), shows that persons who are foreign citizens and who do not have their domicile in Romania, by acts between living persons cannot acquire land ownership rights (without distinction as to what kind of legal or testamentary inheritance), with the obligation to alienate them within one year from the date of acquisition, under the sanction of their free transfer to state ownership. After the republishing of the law, in art. 48, which remained in force even after the abrogation of art. 66-73 of the Land Fund Act through Law no. 54/1998, now abrogated, the possibility for Romanian citizens, irrespective of their domicile (in the country or abroad), to apply for the restitution of the property right, for the lands owned by them, was granted.

The provisions of art. 68 of Chapter V (Legal Circulation of Land) of Law no. 18/1991, which stipulated that natural persons who are foreign citizens and do not have their domicile in Romania, cannot acquire land by acts between living persons and if they acquire land in ownership by inheritance they are required to alienate them within 1 year from the date of the acquisition under the sanction of their free transfer in state property, was abrogated by Law no. 54/1998 on the legal circulation of land.

The provisions of art. 3 of the Law no. 54/1998, in force since 02.06.1998, stipulated that "(1) foreign citizens and stateless persons cannot acquire land ownership. (2) Natural persons having Romanian citizenship and domicile abroad may acquire in Romania, by legal acts between living persons and by inheritance, lands of any kind “.

Law no. 54/1998 was abrogated by art. 8 of Title X of Law no. 247/2005, which provided that in title $\mathrm{X}$, art. 3 , that foreign citizens and stateless persons may acquire ownership of land in Romania under the conditions provided by the special law.

However, the special law on the reestablishment of the right of ownership is Law no. 18/1991 as it was republished in 1998 and then amended in 2005. Acquiring ownership of a land by reconstitution under the Land Fund Laws is an acquisition based either on the status of the former owner of the applicant (hence an acquisition in his own name) or as the heir of the former owner (hence an acquisition as heir). 
And Law no. 18/1991 did not refer, from June 1998, as a result of the abrogation of art. 68, to the acquisition of ownership of land by foreign citizens by of inheritance. But the Constitution of Romania, during this period (1998-2003), that is, until its revision in 2003, prohibited foreign citizens and stateless persons from acquiring ownership of land in Romania. This means that foreign citizens could not acquire even as legal heirs of their author, Romanian citizen, the ownership of the land by means of restitution, under Law no. 18/1991.

It was considered, however, that only art. 48 of the Law no. 18/1991 - special law to Law no. 54/1998-, which referred only to the acquisition of ownership in its own name and allowed it only to the Romanian citizens, regardless of their domicile. Thus, it was expressly stated that only Romanian citizens domiciled abroad or former Romanian citizens who have regained their Romanian citizenship may apply for the restitution of the right to property for agricultural land or forest land only within the limits of certain maximum areas provided by law.

Law no. 312/2005 cannot be considered as a special law for land subject to the restitution of private property rights because it refers to land which is already in the civil circuit and not to land entering the civil circuit by the restitution of the ownership right by issuing of the property title by the competent authorities of Romania.

After the revision of the Constitution in 2003, which by art. 44 par. 2 guarantees and equally protects the right of ownership, regardless of the holder, and expressly stipulates that foreign citizens and stateless persons may acquire the right of private ownership of land by legally inheritance, the provisions of art. 3 par. 1 of Law 54/1998 were declared unconstitutional ${ }^{9}$. Obviously, it was about the inheritances that were opened after the revised Constitution entered into force, that is, after 29.10.2003. They also concerned situations where these lands were included in the succession, that is, the title of restitution had been issued on behalf of the author of the Romanian citizen. Following the revision of the Constitution, foreign citizens may acquire ownership of the restituted land in favor of their author, without having to alienate it within one year of the date of acquisition, as regulated in Art. 68 of Law no. 18/1991, before it was abrogated. Foreign citizens will have this right, regardless of the date of their author's death, the former owner, provided that the reconstitution falls within the scope of the revised Constitution (to be pending on 29.10.2003 or that the proceedings have been initiated after that date, under the Law No 247/2005) ${ }^{10}$.

${ }^{9}$ Decision no. 408 / 07.10.2004 of the Romanian Constitutional Court.

${ }^{10}$ This is also the point of view expressed by Simona Kovacs in the article entitled "The Right of Foreign Citizens to Reconstruct the Land Ownership as Heirs to Their Authors", Judicial Review Magazine, available online at http://www.forumuljudecatorilor.ro/index.php/2009/11/ dreptul-cetatenilor-straini-la-reconstituirea-dreptului-de-proprietate-asupra-terenurilor-in-calitate-de-mostenitori-ai-autorului-lor/. 


\section{c) Restrictions on the acquisition of the right to property required by the exercise of the pre-emption right. Common law regulation}

The right of pre-emption is the right arising from a law ${ }^{11}$ or contract that confers upon its beneficiary, the preemptor, priority in purchasing a good. In the current Civil Code, the right of pre-emption is regulated in the art. 1730-1740 C. civ.

As a legal nature ${ }^{12}$, the right of pre-emption is a potestative right which implies the correlated obligation of the passive subject, that is, the seller-owner, to respect the pre-emption, meaning to allow the preemptor to accept the offer of sale, in which case the potestative right is exercised in a positive manner, or the refusal of this offer, in which case the pre-emption right is exercised in a negative manner.

As far as its legal characters are concerned, the preemption right is, according to art. 1739 C. civ., indivisible and inalienable, being a right constituted intuitu personae. The preemption right is extinguished at the death of the preemptor, except when it has been constituted for a certain period. In the latter case, the term shall be reduced to 5 years from the date it started, if a longer term has been stipulated.

The provisions of the Civil Code concerning the pre-emption are suppletive/ not mandatory, applying only if by law or contract it is not stated otherwise and only in the case of the sale contracts concluded after the entry into force of the current Civil Code, and in the case of conventional pre-emption, only for the agreement concluded after the entry into force of the new Civil Code.

The existence of a pre-emption right, legal or contractual, is a restriction on the freedom of the owner to dispose of his property because he has to fulfill certain formalities, either prior to sale or after the sale of the good, to a third party, in order to ensure the priority of buying to the preemptor.

The vendor may either notify his offer for sale to the preemptor, which can accept it within no more than 30 days in the case of immovable property, or sell directly to a third party the good for which there is a preemption right, but only under the condition precedent the preemption right is not exercised by the preemptor.

In this second situation, art. 1732 C.C. provides for the obligation of the seller to immediately notify the preemptor of the content of the contract concluded with a third party, the notification can be made even by the third party.

${ }^{11}$ For the disclosure of the various preemption cases found in special laws, see G. Boroi, C.A. Anghelescu, B. Nazat, Civil Law. Rights in rem, Edit. Hamangiu, 2013, p. 37 and 38.

${ }^{12}$ Regarding the legal nature of the right of pre-emption as a potestative right, see I. Negru, D. Corneanu (I), A.G. Ilie, M. Nicolae (II), Discussions on the legal nature of the preemption right, in Law no. 1/2004, p. 22 64; D. Chirică, Civil Law Treaty. Special contracts. Volume I. Sale and Exchange, Ed. C.H. Beck, Bucharest, 2008, p. 100; E. Chelaru, Preemption right regulated by Law no. $54 / 1998$, in the Law no. 8/1998, p. 19 et seq. In the sense that the right of preemption is a real right, see Gh. Beleiu, The preemption right regulated by Law no. 18/1991 of the Land Fund, in Law no. 12/1992, p. 3 13; L. Pop, Rights in rem, Ed. S.C. Cordial Lex, Cluj Napoca, 1993, p. 75; I. Adam, The Legal Regime of the Remediation and Acquisition of Real Estate Land and Buildings, Ed. Europa Nova, Bucharest, 1996, p. 76 
The notification must include the surname and forenames of the seller, the description of the good, the charges imposed on it, the terms and conditions of the sale, and the place where the good is located.

If the preemptor decides to exercise his preemption right, he will communicate his sales agreement to the seller, and the communication must be accompanied by the price placed at the disposal of the seller.

Sale based on the preemption right has the character of a real agreement, the preemptor's consent being doubled by the actual price placed at the seller's disposal. The aim of the legislator was to avoid the abuse of rights which the preemptor might be tempted to practice ${ }^{13}$.

The mechanism of exercising the preemption right on the basis of a contract with a third party under the condition precedent of the positive non-exercise of the preemption right by the preemptor is considered to be a balanced one, designed to prevent any fraud of the seller or third party's interests by the preemptor ${ }^{14}$. By the mechanism provided by the legally presumed condition precedent affecting the sale to a third party, the preemptor will not need to seek a nullity of the sale for an immoral cause, an action for the inopposability of the selling or an action for subrogation to the third party's place in the contract ${ }^{15}$.

The condition precedent of not exercising the preemption that affects the sale of the property to a third party is more than this, it becomes an essential element of the validity of the contract, the existence of which is presumed by law. The presumption of the existence of the condition precedent will also apply if the preemption right arises as the result of the parties' agreement ${ }^{16}$.

When, upon receiving of the notification, the preemptor communicates to the seller his sales agreement and proof that the price was placed at the disposal of the vendor, the condition precedent will not be fulfilled, and the sale to a third party is considered never to have been accomplished. If the potestative preemption right is exercised in its negative form, in the form of refusal of the offer, the sale to the third party is reinforced by the fulfillment of the condition precedent.

It has been considere ${ }^{17}$ that the fact that the preemption price is placed at the vendor's disposal by accepting the seller's offer is likely to put him under the shelter of untimely or abusive acceptance of the offer by an insolvent preemptor.

Also, the fact that the sale to the preemptor is a real contract, by placing the price at the vendor's disposal, makes the preemptor unable to rely on the payment terms granted by the seller to the third party.

\footnotetext{
${ }^{13}$ See J. Goicovici, Sale under preempton right, in the regulation of the new Civil Code, in

${ }^{14}$ Ibidem.

${ }^{15}$ Idem, p. 33-34.

${ }^{16}$ Ibidem.

${ }^{17}$ See J. Goicovici, loc. cit., p. 34.
} P.R. no. 5/2012, p. 31. 
In the case of the exercise of the preemption, the good-faith third party, who was unaware of the existence of a conventional preemption right because it did not become opposable through the Land Registry, will be able to promote against the seller warranty claim for eviction.

For the first time, through art. 1734 C. civ., is imperatively regulated the contest between the preemptors and it was taken into account the legal or conventional nature of the preemption, the publicity of the conventional preemption through the registration in the Land Registry if it relates to a real estate, or through the certified date of the act, when the good is mobile.

Thus, in the case of a contest between the beneficiaries of the legal preemption right and those of the contractual preemption rights, the beneficiary of the legal preemption right will have priority.

When there are several beneficiaries of legal preemption rights, the seller has the freedom to choose any of them.

In the case of the existence of several beneficiaries of conventional preemption rights, when the property is immovable, priority will be given to the person who first registered the right in the Land Registry, and if the good is mobile, it will be preferred to the beneficiary of the conventional preemption right whose contract has the oldest certified date.

The parties cannot disregard the applicable competition rules according to the law and cannot by convention set another priority of the preemptors. Such a clause is considered by law to be unwritten and thus free from any legal effectiveness.

Regarding the land from the forest fund, the Civil Code regulates expressly, by the provisions of art. 1746, the fact that these privately owned land can be sold with due respect for the preemption rights of co-owners or neighbors. Naturally, it is about neighbors who have the property of the land which is bordering the land that is being sold.

In the Forestry $\operatorname{Code}^{18}$, as amended by Law no. 60/2012, stipulates that in the event that the land to be sold is close to the public property of the state or of the territorial administrative units, the exercise of the preemption right of the state or of the territorial administrative units, within the stipulated term, prevails over the neighbors' pre-emption right. Consequently, in this particular case, the priority order of purchase will be the following: co-owners, state or territorial administrative units and neighbors.

In order to exercise the pre-emption, the seller has the obligation to notify all the preemptors, through the judicial executor or the notary, in writing, of the intention to sell, showing the asking price for the land to be sold.

${ }^{18}$ The Forestry Code of 19 March 2008 was published in M. Of. no. 238 of March 27, 2008 and completed several times, the last addition being by Law no. 60/2012, published in M. Of. no. 255 of 17 April 2012. 
If the co-owners or neighbors of the fund, other than the forest manger of the forests of the public property, do not have their domicile or offices known, the announcement of the offer for sale shall be recorded at the City Hall or, where applicable, the municipalities City Halls within which the land is located and displayed in the same day, at the Town Hall, through the care of the secretary of the local council.

Beneficiaries of the preemption right must make a written statement of purchase intention and communicate the acceptance of the offer of sale or, if necessary, register it at the City Hall where it was displayed, within 30 days of the communication of the offer of sale or, where applicable, from its display at the City Hall.

If none of the preemptors express their intention to purchase within the timeframe, the sale of the land is free.

Failure by the seller to perform the pre-emption procedure or sell the land at a lower price or under more favorable conditions than those shown in the sale offer renders the sale void.

The provisions on the exercise of the preemption right, as presented above, will apply only to the sales contracts concluded after the entry into force of the Civil Code ${ }^{19}$.

\section{d) Acquisition of the right to property on the agricultural land outside of built-up areas (extra muros - latin), under the conditions provided by the Law no. 17/2014}

As it turns out of the title of this normative act and of the article art. 1 of this, one of the main purposes of the Law no. 17/2014 regarding certain measures for regulating the sale and purchase of extra muros agricultural land and amending Law no. 268/2001 on the privatization of commercial companies owning public and private property of the state with agricultural destination and the establishment of the Agency of State Domains ${ }^{20}$ is to determine the conditions under which the extra muros agricultural land ${ }^{21}$ may be subject to a sale-purchase contract.

The main points of interest of this normative act concern, on the one hand, the subjects of law which may be parties to a sale-purchase contract having as object an extra muros agricultural land and to which its provisions apply, and on the other hand, the technical conditions which they must observe in order for such a contract to be validly concluded.

${ }^{19}$ For an evolution of the regulation of preemption right in the case of forest land, see E. Chelaru, Civil Law. ..., op. cit., 2009, p. 172 175; E. Chelaru, Preemption Right Regulated by the Forestry Code, in Law no. 6/1997, p. 1529.

${ }^{20}$ Published in the Official Monitor, Part I no. 178 of 12.03.2014; enter into force on 11.04.2014.

${ }^{21}$ The provisions of the present law apply exclusively to extra muros agricultural land, those within muros being expressly excluded through art. 2 par. 1 of the Law. 
With regard to the legal subjects to which these legal rules are addressed, the law establishes two legal regimes according to the categories of persons wishing to be parties to a purchase contract for extra muros agricultural land.

In this regard, the first category of persons and the legal regime applicable to them can be derived from the content of art. 2 par. 2. Thus, according to it, "The provisions of the present law apply to Romanian citizens, respectively citizens of a Member State of the European Union, of the States which are party to the Agreement on the European Economic Area (EEA) or of the Swiss Confederation, and of stateless persons domiciled in Romania, in a Member State of the European Union, in a State which is a party to the ESEE or the Swiss Confederation, as well as to legal persons of Romanian nationality, respectively of a Member State of the European Union, of the states that are party to the ESEE or Of the Swiss Confederation.

From the reading of this legal text it can be inferred that the extra muros agricultural land of Romania can be acquired, in compliance with the provisions of this Law, under the same conditions both by the Romanian citizens and by the foreign citizens. The only condition that foreign citizens in this category have to fulfill in order to benefit from the same legal regime as the Romanian citizens is to be a citizen of a Member State of the European Union, of the states that are party to the Agreement on the Economic Space European or Swiss Confederation. extra muros agricultural land May also be acquired under the same conditions as Romanian citizens, by stateless persons if they are domiciled in Romania, in a Member State of the European Union, in a State party to the ESEE or in the Swiss Confederation. At the same time, from the same normative text and under the same conditions stipulated by the Law, extra muros agricultural land can be acquired by Romanian and foreign legal persons, provided that the latter have the nationality of a member state of the European Union, States which are party to the ESEE or the Swiss Confederation.

The second category of persons and the legal regime applicable to them are found in the third paragraph of Art. 2 of the Law. According to this, "a third-country national and a stateless person domiciled in a third country, as well as legal persons having the nationality of a third State, may acquire the right to property on extra muros agricultural land under the conditions laid down in international treaties on the basis of reciprocity, under the terms of this law."

From the content of this normative text there are three essential aspects, namely the existence of an international treaty signed by the states to which the persons concerned belong and which grant them the right to buy extra muros agricultural land in the territory of the other state, this right to be granted under conditions of reciprocity, and in order to acquire the land, the conditions stipulated by the present Law are to be met.

First of all, in order to be able to purchase extra muros agricultural land in Romania, citizens of a third state, stateless persons residing in a third country and 
legal persons having the nationality of a third state, respectively all those persons which cannot be found among the persons listed in the previous paragraph, will be able to acquire the right to property on extra muros agricultural land, providing that there is an international treaty between the states to which the persons in question belong to, expressly states this possibility and the general requirements that have to be met.

Secondly, in order for the prerogative of the acquisition of extra muros agricultural land to exist, it is necessary for the international treaty to establish it on a reciprocal basis. That reciprocity, in the light of those presented in the section devoted to the delimitation of the meaning of this notion, must be understood as a necessary and binding condition in the treaty on which the right of each of the persons of the signatory states to be able to acquire in the other state extra muros agricultural land through a sale-purchase contract is based on.

In order for a citizen from a third country to be able to buy such land on Romanian territory, it is necessary for Romanian citizens to be given the legal opportunity to purchase extra muros agricultural land in the third country. In other words, the impossibility of one of the persons in question to acquire extra muros agricultural land in the other state will automatically prohibit the purchase of such land by the other person of the other state.

Thirdly, in order for the interested persons, namely citizens from third countries, to be able to exercise validly and effectively the right to acquire extra muros agricultural land in Romania, they must obey and comply with the provisions of Law no. 17/2014, which aims at establishing the necessary conditions that the parties to a contract for sale-purchase of extra muros agricultural land must fulfill for its valid conclusion.

Thus, it follows from the combined interpretation of paragraphs 2 and 3 of Art. 2 of the Law, that both categories of persons, provided by the two normative texts, in order to acquire such a land through a sale-purchase contract, must comply with the special rules imposed by the national law, and the conditions of reciprocity that grants the right of third-country nationals to acquire extra muros agricultural land in Romania cannot be expressed in such a manner as to allow them to circumvent, to avoid the provisions of Law no. 17/2014. The interpretation of the two paragraphs must lead us to the idea that, whatever the content of the reciprocal conditions found in the international treaty, they cannot confer on third-country nationals a more favorable legal status than that of nationals of a Member State of the Union European Union, of one of the States which are party to the Agreement on the European Economic Area (EEA) or of the Swiss Confederation.

Also, from the final sentence of paragraph 3, namely that requiring third-country nationals to comply with the conditions of Law no. 17/2014 in order to be able to validly acquire extra muros agricultural land in Romania, we must 
understand that, subject to reciprocity, they cannot be required more severe or more restrictive conditions than the Romanian citizens and the others listed in par. 2 of art. 2 of the Law, the latter being, in their turn, also compelled to observe the provisions of Law 17/2014.

Synthesizing these latest ideas, we conclude that, in the case of citizens from a third state, they, in the presence of reciprocity clauses stipulated in the international treaty signed by Romania with a third state, will be able to acquire extra muros agricultural land on the territory of Romania, provided that they comply with the provisions of Law 17/2014, thus benefiting from the same legal status as the Romanian citizens, who are also subject to the same legal provisions in the matter.

Once we have reviewed the issues regarding the categories of persons to whom the provisions of the law apply, we continue with its second point of interest, namely the technical, substantive and formal conditions to be observed by the parties to a contract sale-purchase of extra muros agricultural land in Romania.

In this regard, according to art. 4 par. 1 of the Law, "The transfer, by sale, of the extra muros agricultural land shall be done in compliance with the substantive and form conditions provided by the Law no. 287/2009 on the Civil Code and the preemption right of the co-owners, lessees, neighbors and the Romanian state, through the Agency of State Domains, in this order, at an equal price and under equal conditions." So, having this provisions into consideration, the substantive and formal conditions to be complied with in the case of the sale of a extra muros agricultural land, these are the general provisions laid down in this regard by the Civil Code in Title IX, Chapter I, of the sale-purchase contract in conjunction with the other normative texts of the Civil Code, which regulates the transfer of the land ${ }^{22}$.

Among these conditions, we also find that complying with the right of preemption. As it results from the previously normative text, the beneficiaries of the preemption right $\operatorname{are}^{23}$, in this order, the co-owners, the lessees, the neighbors and the Romanian state. Along with the general legal regime which the Civil Code draws, in the art. 1730-1740, this Law provides for some special, derogatory provisions which the parties must obey in this matter.

Thus, according to art. 6 of the Law, in order to inform the preemptors of the intention to dispose of the agricultural land, the seller records, at the Town Hall within the territorial-administrative unit where the land is located, an application requesting the display of the offer for sale of the extra muros agricultural land. The application shall be accompanied by the offer for sale of the agricultural land and the supporting documents stipulated by the methodological norms for

\footnotetext{
${ }^{22}$ We take into consideration the requirements imposed by the Land Registry provisions in the Civil Code.

${ }^{23}$ An overview of the preemption right has already been made in a previous section, reason for which, within this section, we will limit ourselves to presenting only the specific provisions characteristic of the preemption right stipulated by Law 17/2014.
} 
the application of this Law. Next, within one working day of filing the application, the City Hall is requested to display the offer for sale for 30 days and, when applicable, on its website. Also, the mayor's office has the obligation to send to the structure within the central department of the Ministry of Agriculture and Rural Development, and its territorial structures, a file containing the list of preemptors, the copies of the display request, the offer for the sale and the supporting documents, in within 3 working days from the date of filing the application. Following the registration of the submitted file, the central structure and the territorial structures of the Ministry of Agriculture and Rural Development have the obligation to display on their own sites the offer of selling the extra muros agricultural land for 15 days.

On the other hand, in accordance with the provisions of Art. 7 of the Law, the beneficiary of the preemption right must within the 30 days express his written intention to purchase, communicate the acceptance of the seller's offer and register it at the City Hall where it was displayed, following that the City Hall shall display, within 24 hours from the registration of the acceptance of the offer of sale, the data provided for in the methodological norms for the application of this Law, as well as send them for display on the site to the central structure, respectively the territorial structures of the Ministry of Agriculture and Rural Development, depending on the situation.

In the event of a competition between same rank preemptors or higher and lower rank preemptors, the solution is provided by the contents of paragraphs 2 , 3 and 4 of Art. 7 of the Law. Thus, if, within 30 days, more preemptors of different rank express their written intention of buying, at the same price and under the same conditions, the seller will choose, in accordance with the provisions of art. 4 of the Law, the potential preemptor buyer and will communicate his name to the City Hall. This choice will be made in compliance with the provisions of art. 4 of the Law, which, in their turn, refer to the legal regime of the preemption right outlined in the Civil Code, the rules for solving the conflict between preemptors being found in art. 1734. If several preemptors of the same rank express their written intention of purchasing and no other superior ranking preemptor accepts the offer at the same price and under the same conditions, the one who will choose between them will be the seller and will communicate the name of the chosen one to the City Hall. The last hypothesis of conflict found in the art. 7 of the Law is the one which, within 30 days, a lower-ranking preemptor offers a higher price than the one in the sale offer or in relation to that offered by the other preemptors of higher rank who accepted the offer. Under this circumstance, the seller may resume the procedure with senior (higher rank) preemptors, registering the offer for sale with the new highest price.

If, within the period of 30 days set for the preemption right, none of the beneficiaries of this right has the intention to buy the land, the sale of the land is 
free, complying with the provisions of this Law and the methodological norms and followed by the fact that the vendor will notify the City Hall in writing of this. However, the sale will be free, provided that it is executed in accordance with the terms of the sale offer made in order to observe the preemption right, under the condition of absolute nullity, the sale cannot be carried out on more advantageous terms than the ones in the offer and not for a lower price.

The supervision of the application and observance of the preemption right is carried out by the central structure, respectively by the territorial structures of the Ministry of Agriculture and Rural Development at the place of the immovable property, as the case may be, within 5 working days after receiving the data and the documents requested by art. 6 and 7 of the Law. If, following the verification, it is found that the rules imposed by the preemption right have been respected, the permit required to conclude the sale-purchase contract will be issued and if no preemptor expresses his intention to purchase by submitting the offer in the time limit provided in the present law, the issuing of the permit is not necessary. In the latter hypothesis, the sales contract will be concluded on the basis of the certificate issued by the City Hall.

In conclusion, subject to the conditions stipulated by the present Law, the categories of persons, both natural and legal, Romanian and foreign, mentioned in this normative act, will be able to acquire validly the ownership right over the extra muros agricultural land on Romania's territory.

\section{e) Restrictions on the acquisition of the ownership right related to the form of the act of the transfer of land}

Article 1244 of the Romanian Civil Code provides that "Except for other cases provided by law, must be concluded by authenticated document, under sanction of absolute nullity, the agreements which transfer or constitute real rights and that are to be entered in the Land Registry."

Although the marginal name of art. 1244 C. civ. is the "Form Required for entering in the Land Registry", the intention of the legislator was that the authentic form be a condition of validity of any act by which real rights on immovable property are created or transferred, and not a condition of opposability to third parties. This is because, through art. 885 par. (1) C. civ., the entering of the contract in the Land Registry is given a constitutive effect of right: "Subject to contrary legal provisions, the real rights over the buildings found in the Land Registry are acquired both between the parties and towards third parties, only by entering them in the Land Registry, based on the act or fact that justified the entering."

The fact that technical impediments in finalizing the cadastral works in every territorial administrative unit determined the postponement of the application of the provisions of art. 885 par. (1) Romanian Civil Code, in the sense that, by art. 56 
of the Law no. 71/2011 for its implementation, the entering in the land register is made only for the purpose of being opposable to third parties, without having the constitutive effect of right, should not lead us to the idea that the authentic form of the transfer of land with or without construction or just construction, has become only a condition of opposability to third parties. It is true that in order to make an entry in the Land Register the real right constituted or transferred it is necessary either a authentic document (authenticated by a notary), either a judicial decision or an administrative document, when the law so provides. Undoubtedly, by the provision of art. 56 of the Law no. 71/2011, the intention of the legislator was not to suppress the authentic form of constitution or transfer of immovable goods, so that the interpretation of these provisions must take into account the spirit of the law and not just the letter of the text.

Under these circumstances, any conventional transfer of a real right of immovable property entered in the Land Registry or about to be entered, land with or without construction, or only construction, and any contract constituting a dismemberment of the right ownership of an immovable property registered or to be entered in the Land Register must be completed in authentic form.

Failure to comply with this formal requirement of the translative or constitutive contract of real right results in the sanction of absolute nullity. On the basis of the same reasoning, the option pact concerning the transfer of ownership of real estate must be concluded in authentic form.

Authentic form is not mandatory in the case of bilateral promises to sell a land, regardless of its nature, that is to say, if the parties bind themselves to conclude at a certain term the translative property contract. 
Др Ирина Сфердиан, иррофесор

Зайадни универзитетеи у Темищвару

Правни факулиетеи

irina.sferdian@e-uvt.ro

Др Кодруиа Гузеи-Манг̄y, вищи ирредавач

Зайадни универзитетеи у Темищвару

Правни факулиетеи

codruta.mangu@e-uvt.ro

\section{Стицање права својине на земљишту од стране страних држављана у Румунији}

Сажейак: Рад се бави сииицањем иррава својине на земљищйу од стиране стираних држављана у Румунији. У раду су изложени йравни ирроблеми у овој майерији у вези са йравним режимом који је усйостиављен са иири кључа закона, Законом 312/2005, Законом 18/1991 и Законом 17/2014, као и у вези са устиавним одредбама које се тиччу ове ирроблемайике. У Румунији се йравни режими за стиицање йрава својине на земљищйу од стиране стираних држа-

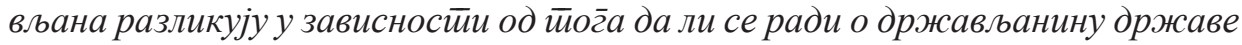
чланице Евройске уније или о сйраниу из неке тиреће земље. У истиражсивағу је йажњ йосвећена и објашњењу ӣојма узајамносиии у овој маиеерији и функиионисаюу механизма иррава иррече куйовине у кониеексйу стиицања йрава својине од ситране сииранача у Румунији.

Кључне речи: стиицање йрава својине на земљищйу у Румунији, стирани држављани, йољоиривредно земљищйе, неиокретиносиии, йраво иррече куйо-

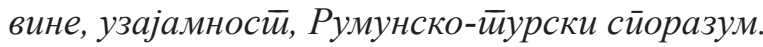

Датум пријема рада: 18.09.2017. 